\title{
Electrolyte Concentration in Malarial Patients by Flame Photometer
}

Saira Baloch" ${ }^{1 *}$, G.S.Gachal', S. A. Memon ${ }^{2}$ and Marya Baloch ${ }^{2}$

${ }^{1}$ Department of Zoology, University of Sindh, Jamshoro, Pakistan

${ }^{2}$ Dr.M.A.Kazi, Institute of Chemistry, University of Sindh, Jamshoro, Pakistan

\begin{abstract}
Malaria is a life-threatening disease caused by the parasite. It could be a major public health problem in Pakistan due to poor hygienic conditions; malnutrition borne non-defensive immunity system. The purpose of study was to examine possible changes in electrolytes level of patients with malaria. Serum electrolytes were determined by using appropriate techniques. The result showed a significant elevation in the levels of sodium (Na) and potassium (K), whereas, chloride decreases statistically in malarial patients compared to those of controls. The blood serum electrolyte level obtained for sodium was $135.55 \mathrm{ppm}$, potassium was $4.044 \mathrm{ppm}$, and for chloride was $10.33 \mathrm{ppm}$ and those for the controls determined to be $130.88 \mathrm{ppm}, 3.98 \mathrm{ppm}$ and $104.5 \mathrm{ppm}$ respectively.
\end{abstract}

The concentration of serum electrolytes was in range of abnormal level which could lead our study towards the conclusion that the increased levels of sodium and potassium can be maintained by giving supplement.

Keywords: Electrolytes; Serum; Malaria; Flame photometer

\section{Introduction}

Malaria is the parasitic disease. The world health organization (world health organisation) estimates that 270 million new malaria infections occur worldwide along with 110 million cases of illness and 2 million deaths where $25 \%$ of childhood deaths in africa are attributed to malaria [1]. Common electrolytes that are usually measured sodium, potassium and chloride [2-4]. Sodium $\left(\mathrm{Na}^{+}\right)$is the major cation of extra cellular fluid and as such plays a central role in the maintenance of the normal distribution of water and osmotic pressure in various fluid compartments [9]. Potassium $\left(\mathrm{K}^{+}\right)$on the other hand is the major intracellular cation, having an average cellular concentration in tissue cells of $150 \mathrm{mmol} / 1$ [7].

In addition to water balance, these electrolytes play an important role in maintenance of ph, regulation of heart and muscle function, electron transfer reactions as well as serving as cofactors for enzymes [8]. Disorders of water balance include Hyponatreamia, Hypernatraemia, Hypokalaemia and Hyperkalaemia, which also occur in conditions of electrolyte disturbance, such as severe malaria infection [6]. Kakkilaya, et al. [6] observed that malaria is often associated with abnormalities of fluid, electrolytes $\left(\mathrm{Na}^{+}\right.$and $\left.\mathrm{K}^{+}\right)$and acid-base balance. These can occur in anybody but are more common in severe falciparum malaria, extremes of age and in patients with high degree of fever and vomiting [5].

\section{Material and Method}

Fifteen venous blood samples $(10 \mathrm{ml})$ of both the groups each from malarial patients and control subjects were collected into sample tubes without the addition of anticoagulant. The blood samples were centrifuged at $1500 \mathrm{rpm}$ for 20 minutes; the serum was separated and immediately used for the determination of the electrolytes, sodium, potassium and chloride was analyzed using flame photometer (M-410 CORNING).

All the chemicals and reagents obtain were of analytical grade obtained from Merck.

\section{Determination of serum potassium}

The principal reaction is based on measuring; at an alkaline $\mathrm{pH}$ potassium ions and (TPB) form a turbid emulation, the formation of which can be measured quantitatively in a photometer at $578 \mathrm{~nm}$. The increase of the absorbance (A) is directly proportional to the concentration of potassium in the sample $1000 \mu \mathrm{l}$ of reagent sodium hydroxide, TPB-Na (R1) followed by reagent kalium (R2) in a $5 \mathrm{ml}$ sample tube containing $10 \mu \mathrm{l}$ blood serum were mixed and allowed to stand for 10 minutes to complete the reaction. The absorbance was measured at wavelength $578-546 \mathrm{~nm}$ which showed the relationship between the content of alkaline phophatase and the absorbance of Ca-MTB formation in a linear manner. The day-to-day variation is less than $3 \%$ (Figure 2).

\section{Determination of serum sodium}

The principle reaction is based on measuring at sodium magnesium uranyl acetate. The excess of uranium was reacted with Ferrocyanide to produce a chromophore, the formation of which can be measured quantitatively in a photometer at wavelength at $550 \mathrm{~nm}$. The increase of the absorbance (A) is directly proportional to the concentration of sodium in the sample (Figure 1).

\section{Determination of serum chloride}

$1000 \mu \mathrm{l}$ of reagent mercuric (ii) thiocynate, mercuric (ii) chloride (R1) followed by reagent Ferric (iii) Nitrate Nitric Acid (R2) in a $5 \mathrm{ml}$ sample tube containing $10 \mu \mathrm{l}$ blood serum were mixed and allowed to stand for 10 minutes to complete the reaction. The absorbance was measured at wavelength $436 \mathrm{~nm}$, which showed the relationship between the content of alkaline phophatase and the absorbance of $\mathrm{Ca}$ MTB formation in a linear manner. The day to day variation is less than 3\% (Figure 3).

\section{Results and Discussion}

Table 1 show the blood serum levels of electrolytes in healthy con-

*Corresponding author: S Baloch, Department Of Zoology, University of Sindh, Jamshoro, Pakistan, E-mail: Saira_Dr01@Yahoo.Com

Received August 22, 2011; Accepted October 25, 2011; Published October 29 2011

Citation: Baloch S, Gachal GS, Memon SA, Baloch M (2011) Electrolyte Concentration in Malarial Patients by Flame Photometer. J Bacteriol Parasito 2:123. doi:10.4172/2155-9597.1000123

Copyright: (C) 2011 Baloch S, et al. This is an open-access article distributed under the terms of the Creative Commons Attribution License, which permits unrestricted use, distribution, and reproduction in any medium, provided the original author and source are credited. 
trol subjects and table 2 show electrolytes levels in malarial patients. The results show significant increase in serum sodium and potassium as compared to the control subjects, whereas, serum chloride level decreases in malarial patients as compared to the control subjects.

\section{All Values Are Expressed As Mean \pm S.D}

From the above data it was observed that the electrolyte sodium and potassium increases significantly whereas serum levels of chloride decreases in malarial patients as compared to that in the control subjects.

\section{Sodium}

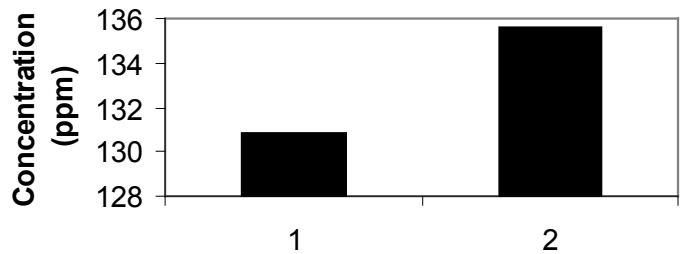

\section{Controls Malarial Patients}

Figure 1: Shows the increased level of serum sodium in malarial patients as compared to the control subjects.

\section{Potassium}

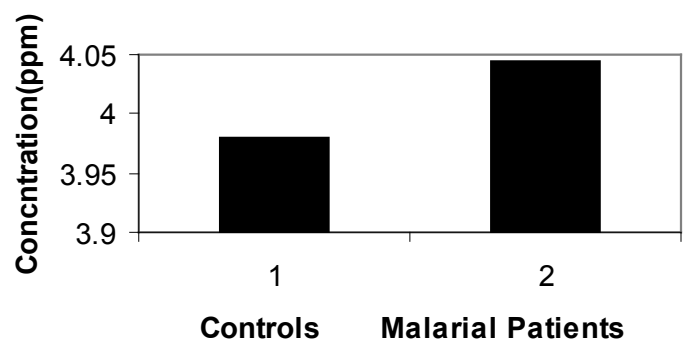

Figure 2: shows the increased level of serum potassium in malarial patients as compared to the control subjects.

\section{Chloride}

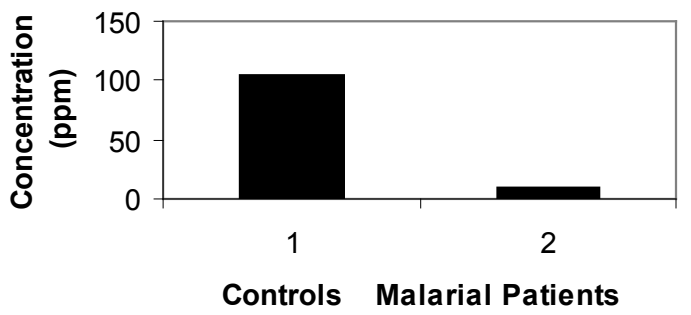

Figure 3: shows the decrease level of serum chloride in malarial patients as compared to the control subjects.

\begin{tabular}{|l|c|c|c|}
\hline & $\begin{array}{c}\text { Sodium } \\
(\mathrm{Mg} / \mathrm{dl})\end{array}$ & $\begin{array}{c}\text { Potassium } \\
(\mathrm{Mg} / \mathrm{dl})\end{array}$ & Chloride \\
\hline Mean & 130.88 & 3.98 & 104.5 \\
\hline Standard Deviation & 8.6918 & 0.4460 & 2.7772 \\
\hline $\begin{array}{l}\text { Relative Standard } \\
\text { Deviation }\end{array}$ & 0.0664 & 0.1120 & 0.0265 \\
\hline
\end{tabular}

Table 1: Blood serum levels of healthy control subject.

\begin{tabular}{|l|c|c|c|}
\hline & $\begin{array}{c}\text { Sodium } \\
(\mathrm{Mg} / \mathrm{dl})\end{array}$ & $\begin{array}{c}\text { Potassium } \\
(\mathrm{Mg} / \mathrm{dl})\end{array}$ & Chloride \\
\hline Mean & 135.55 & 4.044 & 10.33 \\
\hline Standard Deviation & 4.790 & 0.1781 & 4.2213 \\
\hline $\begin{array}{l}\text { Relative Standard } \\
\text { Deviation }\end{array}$ & 0.0353 & 0.0440 & 0.0408 \\
\hline
\end{tabular}

Table 2: Blood serum levels of malarial patients.

Malaria is the major reason of mortality and morbidity in the tropical and sub tropical regions in the world. An estimated 300-500 million people suffer from malaria every year and more than 1 million die each year(world health organisation).it is observed that, electrolytes sodium and potassium increases significantly whereas, the chloride decreases in malarial patients as compared to the control subjects. The blood serum electrolytes determined for sodium was $135.55 \mathrm{ppm}$, for potassium was $4.044 \mathrm{ppm}$, and for chloride was $10.33 \mathrm{ppm}$ and those for the control subjects determined to be $130.88 \mathrm{ppm}, 3.98 \mathrm{ppm}$ and $104.5 \mathrm{ppm}$ respectively.

It is reported that urinary potassium waste and hypokalemia are common complications of severe malaria as well as potassium depletion becomes evident that the correction of acidosis [12].

Chairul Yoel, et al. [13] reported that the concentrations of sodium, potassium, and chloride during malaria were within normal range. Whereas, [14] reported that the malaria infection results in reduced levels of serum sodium and potassium.

The present study shows that there are significant elevated level of serum sodium, potassium and lower level of serum chloride. In malarial patients as compared to the controls been found. The study further shows the importance of electrolyte metabolism management in malarial patients to prevent electrolyte imbalance.

\section{Conclusion}

It is concluded that the imbalance of electrolytes can be maintained by mandatory supplements intake. Our study suggested that along with electrolytes, antimalarial drugs should be prescribed which could help to improve the treatment strategy during and after malaria for the maintaining of electrolyte level balance.

\section{References}

1. http//www.malariatest.com/malaria

2. Mockenhaupt FS, Ehrhardt J, Burkhardt S, Bosomtive S, Laryea S, et al. (2004) Manifestation and outcome of severe malaria in children in Northern Ghana. Am J Trop Med Hyg 71: 167-172.

3. Microlab 300 User Manual: Merck Publishers, Merak.

4. http://www.thefreedictionary.com/cholesterol

5. Heindricks RG, Hassan AH, Olurinde LO, Akindkani A (1971) Malaria in early childhood. Annals of Tropical Medicine 65: 316-320.

6. Kakkilaya BS (1997) Malaria: In Parks Textbook of Preventive and Socia Medicine. (15 ${ }^{\text {th }}$ edn), K Park.

7. Kaplan A, Rhona J, Ophein EO, Toivola B, Lyon W, et al. (1995) Water balance, osmolality, blood gases, $\mathrm{Ph}$ and electrolytes: in Clinical Chemistry, Interpretation and Techniques.(4thedn), Williams and Wilkins, USA.

8. Mayne DP (1994) Sodium, Potassium and water metabolism: In clinica chemistry in diagnosis and treatment. (6thedn), Arnold Euston Publishers, London.

9. Tietz N, Pruden LE, Andersen S (1996) Electrolytes: In Tietz Fundamentals of Clinical Chemistry. ( ${ }^{\text {nd }}$ edn), WB Saunders Company, USA. 
Citation: Baloch S, Gachal GS, Memon SA, Baloch M (2011) Electrolyte Concentration in Malarial Patients by Flame Photometer. J Bacteriol Parasitol 2:123. doi:10.4172/2155-9597.1000123

Page 3 of 3

10. Tietz N, Pruden LE, Andersen S (2001) Electrolytes: In Tietz Fundamentals of Clinical Chemistry, (5thedn), WB Saunders Company, USA.

11. Regional guidelines on the management of severe falciparum malaria in level II Hospitals (2004). World Health Organization South East Asia - Asia Regional Office New Delhi

12. Kathryn Maitland (2005) Perturbations in electrolyte levels In kenyan children with severe malaria complicated by acidosis. Clin Inf Dis 40: 9-16.
13. Maitland K, Pamba A, Newton CR, Lowe B, Levin M, et al. (2004) Hypokalemiain children with severe falciparum malaria. Pediatr Crit Care Med 5: 81-85.

14. Chairul Yoel (2007) Clinical symptoms and electrolytes description of children with malaria an outpatient setting in kabupaten mandailing natal. Majalah Kedokteran Nusantara.

15. Ebele J Ikekpeazu, Emeka E Neboh, Nnenna C Aguchime (2010) Malaria parasitaemia: Effect on serum Sodium and Potassium levels. Biology and Medicine 2: 20-25. 